\title{
PEMBUATAN SISTEM INFORMASI PENDAFTARAN KADASTER 3D BERBASIS WEB (Studi Kasus: Rumah Susun Grudo, Surabaya)
}

\author{
Isna Dwi Lestari, Yanto Budisusanto \\ Departemen Teknik Geomatika FTSP-ITS, Kampus ITS Sukolilo, Surabaya, 60111 \\ Email : isnad109@gmail.com, yanto_b@geodesy.its.ac.id
}

\begin{abstract}
Abstrak
Pada saat ini tingkat kebutuhan akan ruang sangat tinggi, sehingga dirasakan konsep ruang, baik hunian maupun komersial pada umumnya bangunan fisik yang berdiri di atas permukaan tanah (landed house) menjadi kurang efisien. Selain itu, pertumbuhan populasi manusia yang cukup tinggi menyebabkan meningkatnya kebutuhan akan lahan. Untuk mengatasi kebutuhan tersebut sejak tahun 1985 di Indonesia diperkenalkan konsep hunian secara vertikal. Salah satu contoh hunian vertikal yaitu Rumah Susun. Untuk bangunan rumah susun penerapan sistem kadaster dua dimensi (2D) menjadi kurang tepat, karena tidak dapat menggambarkan keadaan yang sebenarnya. Keterbatasan persil 2D ini mendorong lahirnya konsep kadaster tiga dimensi (3D) yang diharapkan dapat memberikan kepastian hukum bagi kepemilikan atas bagian properti rumah susun. Pada pembuatan sistem informasi kadaster 3D, perlu dilakukan pembuatan model 3D dan basis datanya. Pembuatan model 3D dilakukan dengan menggunakan perangkat lunak SketchUp Make, sedangkan untuk pembuatan basis data dilakukan dengan menggunakan perangkat lunak PostgreSQL. Setelah kedua komponen tersebut terbentuk, kemudian komponen tersebut dihubungkan dan divisualisasikan pada website. Dalam pembuatan website dilakukan dengan bahasa pemrograman HTML, CSS dan PHP. Pada penelitian ini berhasil dilakukan pembuatan model 3D dari Rumah Susun Grudo Surabaya dengan tingkat kedetailan dari model 3D yang dibuat didasarkan pada LOD1 (Level of Detail 1), dan pembuatan sistem basis data kadaster 3D. Selain itu, model 3D dari Rumah Susun Grudo berhasil divisualisasikan pada website Sistem Informasi Pendaftaran Kadaster 3D yang telah dibuat. Website tersebut dapat diakses secara online dengan domain www.tridisun-grudo.com. Dari website yang telah dibuat dilakukan pengujian dengan cara pemberian penilaian dari pengguna melalui kuesioner uji kebergunaan atau usability yang terdapat pada website. Berdasarkan hasil rekapitulasi uji kebergunaan total 94 responden dengan presentase hasil sebesar 84,56\%, artinya website Sistem Informasi Pendaftaran Kadaster 3D dikategorikan sangat layak.
\end{abstract}

Kata Kunci: Rumah Susun Grudo, Kadaster 3D, Sistem Informasi, Uji Kebergunaan, Website

\section{PENDAHULUAN}

Menurut Direktur Jenderal Pembiayaan Perumahan Kementerian PUPR, Maurin Sitorus mengatakan bahwa kebutuhan akan perumahan hingga tahun 2025 diperkirakan mencapai lebih dari 30 juta unit, sehingga kebutuhan rumah baru diperkirakan mencapai 1,2 juta per tahun (Julianto, 2016). Dengan begitu, sehingga dirasakan konsep ruang, baik hunian maupun komersial pada umumnya bangunan fisik yang berdiri di atas permukaan tanah (landed house) menjadi kurang efisien. Selain itu, pertumbuhan populasi manusia yang cukup tinggi telah menyebabkan peningkatan konsumsi manusia terhadap lahan. Kapasitas yang terbatas untuk penyediaan lahan sudah mencapai puncaknya, terutama di daerah perkotaan. Kota dengan luas tanah yang terbatas maka tidak dapat menjawab hal tersebut. Untuk menjawab kebutuhan tersebut sejak tahun 1985 di Indonesia diperkenalkan konsep hunian vertikal dalam suatu Undang-Undang tentang Rumah Susun. Undang-
Undang tersebut mengatur tentang tata cara pembangunan, pemilikan, penghunian dan pengelolaan rumah susun; bangunan-bangunan tersebut dikenal sebagai properti strata title.

Istilah strata title merupakan istilah yang memberikan pengertian hukum bagi bangunan gedung bertingkat yang digunakan secara multi fungsi yang mengandung sistem pemilikan perseorangan atau hak bersama. Bagi kepemilikan properti strata title, penerapan sistem kadaster dua dimensi (2D) kurang tepat, karena tidak dapat menggambarkan keadaan yang sebenarnya. Keterbatasan persil 2D ini mendorong lahirnya konsep kadaster tiga dimensi (3D) yang diharapkan dapat memberikan kepastian hukum bagi kepemilikan atas bagian properti strata title (Rusmawar, 2012). Kadaster 3D akan dapat memberikan informasi keakuratan data yang lebih baik di dalam memahami dan menginterpretasi peta, serta kemampuan menampilkan bentuk yang 
lebih perspektif secara real dari bangunan fisik yang ada.

Oleh karena hal tersebut di atas, maka penelitian ini dilakukan untuk membuat suatu sistem informasi pendaftaran kadaster 3D berbasis web, yang mana sistem ini nantinya mampu memberikan informasi terkait keruangan atau informasi spasial 3D dan dapat digunakan untuk melakukan pendaftaran kadaster 3D secara online. Selain itu dengan adanya sistem ini dapat membantu pemerintah dalam mengelola Rumah Susun. Pengujian usability terhadap tampilan website sistem informasi pendaftaran kadaster 3D dilakukan untuk mengetahui sejauh mana sistem yang dibangun memberikan manfaat untuk penggunanya.

\section{METODE}

Rumah Susun Grudo yang terletak di Kelurahan Dr. Soetomo, Kecamatan Tegalsari, Surabaya menjadi obyek pada penelitian ini. Rumah Susun Grudo terdiri dari 5 lantai dan 108 unit ruangan. Tampilan lokasi penelitian dapat dilihat pada Gambar 1.

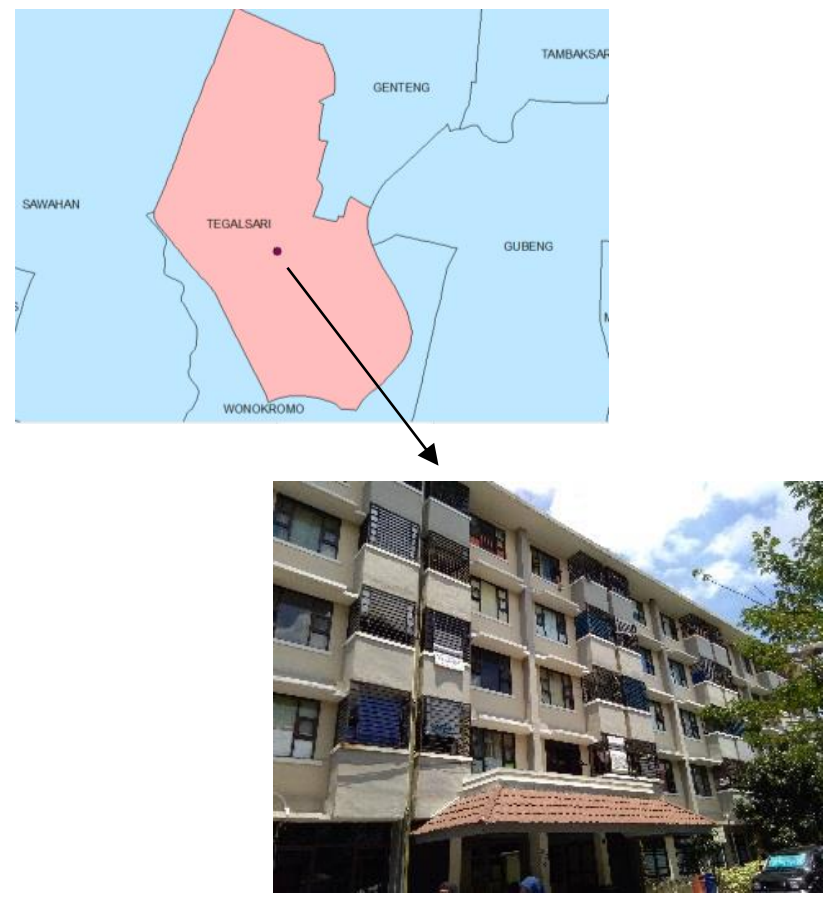

Gambar 1: Rumah Susun Grudo

Penelitian ini menggunakan data denah bangunan, data penghuni, data biaya sewa rumah susun, biaya listrik dan air Rumah Susun Grudo, Surabaya. Data tersebut sebagai atribut dari setiap informasi yang dimunculkan pada jendela informasi setiap ruang.

Pembuatan Model 3D denah Rumah Susun Grudo menggunakan perangkat lunak SketchUp Make menggunakan tool push/pull yang kemudian ditarik atau didorong sesuai dengan ketinggian yang dibutuhkan. Model 3D yang dibuat disesuaikan dengan LOD1 (level of detail 1). Visualisasi Model 3D sebagai langkah selanjutnya dilakukan menggunakan tools visualisasi model 3D di Sketchfab. Untuk visualisasi di Sketchfab model 3D yang telah dibuat di SketchUp harus dikonversi ke format*.dae.

Gambar 2 adalah model konseptual menggunakan ER Diagram untuk basis data yang akan dibangun. Perancangan logikal mentransformasikan ke dalam model data yang sesuai dengan SMBD yang dipilih. Selain itu dilakukan penentuan atribut utama (primary key) dan atribut tamu (foreign key). Untuk model perancangan logikal pada penelitian ini, dapat dilihat pada Gambar 3.

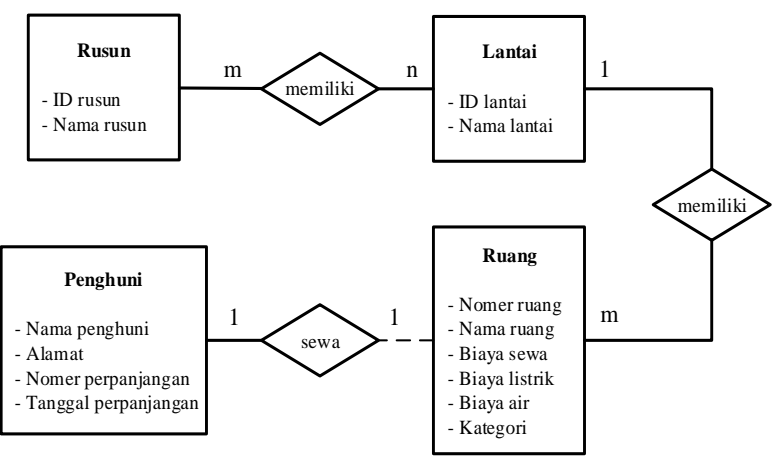

Gambar 2: Model Konseptual Basis Data

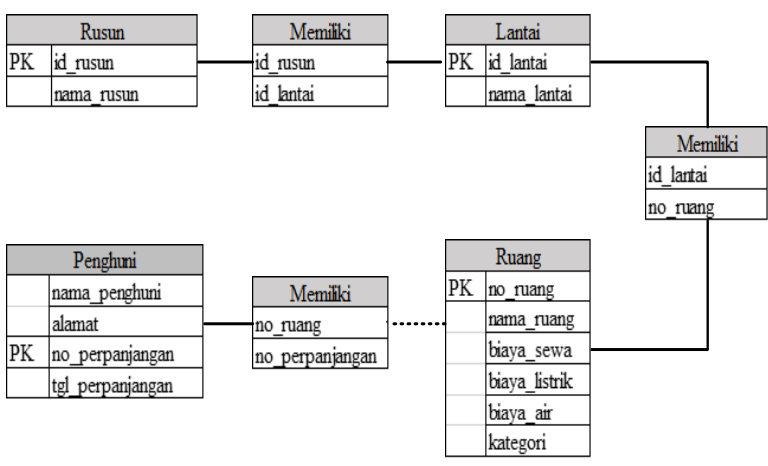

Gambar 3: Model Logikal Basis Data

Perancangan Fiskal mendefinisikan basis data yang akan disimpan sesuai dengan SMBD yang digunakan yang meliputi struktur penyimpanan data, format data, dan jalur akses (lihat tabel 1). 
Tabel 1. Tabel Model Fiskal Basis Data

\begin{tabular}{cllcc}
\hline Tabel & \multicolumn{1}{c}{ Atribut } & Tipe data & $\begin{array}{c}\text { Lebar } \\
\text { Data }\end{array}$ & Key \\
\hline \multirow{2}{*}{ Rusun } & id_rusun & Integer & 10 & PK \\
& nama_rusun & Varchar & 50 & \\
& id_lantai & Varchar & 10 & PK \\
& nama_lantai & Varchar & 50 & \\
& id_rusun & Varchar & 10 & FK \\
& no_ruang & Integer & 10 & PK \\
& nama_ruang & Varchar & 50 & \\
& biaya sewa & Integer & 10 & \\
& biaya_listrik & Integer & 10 & \\
& biaya_air & Integer & 10 & \\
& kategori & Varchar & 50 & \\
& id_lantai & Varchar & 10 & FK \\
& nama_penghuni & Varchar & 100 & \\
& alamat & Varchar & 100 & \\
Penghuni & no_perpanjangan & Varchar & 50 & PK \\
& tgl_perpanjangan & Varchar & 50 & \\
& no_ruang & Integer & 10 & FK \\
\hline \multirow{7}{*}{ Ruang } & & &
\end{tabular}

Perancangan Sistem Informasi Pendaftaran Kadaster 3D memperhatikan visualisasi dari sistem yang mudah digunakan oleh pengguna secara online. Uji Usability terhadap tampilan pada jendela website sistem informasi pendaftaran kadaster 3D menilai kebergunaan dari sisi pengguna. Pengujian usability dilakukan dengan pengisian kuisioner yang telah disediakan pada website oleh pengunjung website (user). Berdasarkan hasil penilaian user maka dapat diketahui tingkat kebergunaan dari website yang dibuat.

\section{HASIL DAN PEMBAHASAN}

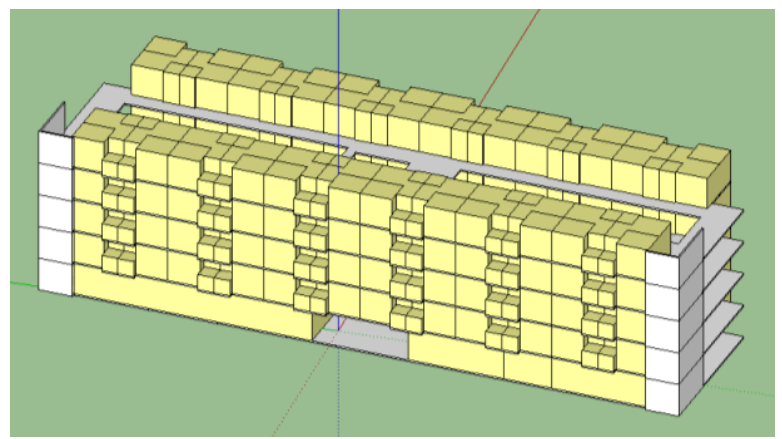

Gambar 4: Hasil Pembuatan Model 3D

Gambar 4 menggambarkan model 3D dari Rumah Susun Grudo mulai dari lantai 1 sampai lantai 5. Di mana pada lantai 1 terdiri dari ruang pengelola, perpustakaan, kamar penghuni, mushola, tempat wudhu, ruang komersil, ruang panel, ruang pertemuan, dan tempat parkir. Sedangkan untuk lantai 2 sampai lantai 5 terdiri dari 24 satuan rumah susun (kamar penghuni) untuk setiap lantai.

Proses pengolahan data atribut dilakukan dengan perangkat lunak PostgreSQL (pgAdmin III). Berdasarkan data yang telah diperoleh dari Dinas Pengelola Bangunan dan Tanah (DPBT) Kota Surabaya, maka dalam penelitian ini terdapat 4 kategori tabel atribut. Keempat tabel atribut tersebut yaitu tabel rusun, tabel lantai, tabel ruang dan tabel penghuni.

Pada tabel rusun berisi informasi mengenai rumah susun yang ada di Surabaya, yakni terdapat 18 unit rumah susun. Tabel rusun dapat dilihat pada Gambar 5. Sedangkan pada tabel lantai berisi informasi mengenai lantai yang ada di Rumah Susun Grudo, yakni terdapat 5 lantai. Tabel lantai dapat dilihat pada Gambar 6 .

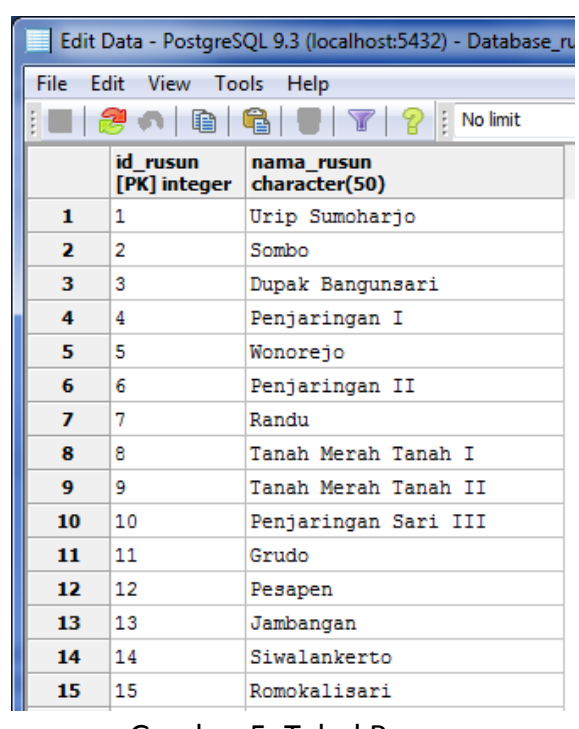

Gambar 5. Tabel Rusun

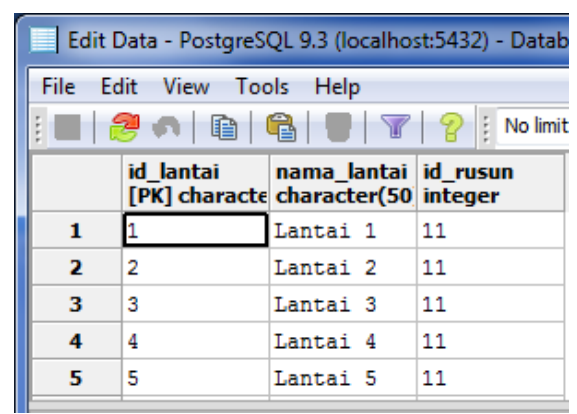

Gambar 6. Tabel Lantai 


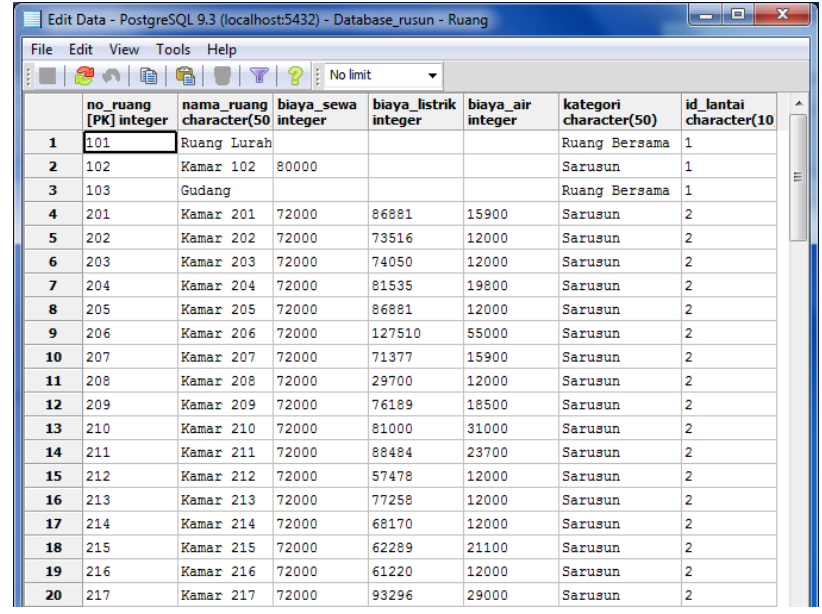

Gambar 7. Tabel Ruang

Pada tabel ruang seperti yang ditunjukkan pada gambar 7 berisi informasi mengenai ruang yang ada di Rumah Susun Grudo, yakni terdapat 108 ruang. Sedangkan pada tabel penghuni seperti yang ditunjukkan pada Gambar 8 berisi informasi mengenai data penghuni rusun yang tinggal di Rumah Susun Grudo, yakni terdapat 97 penghuni.

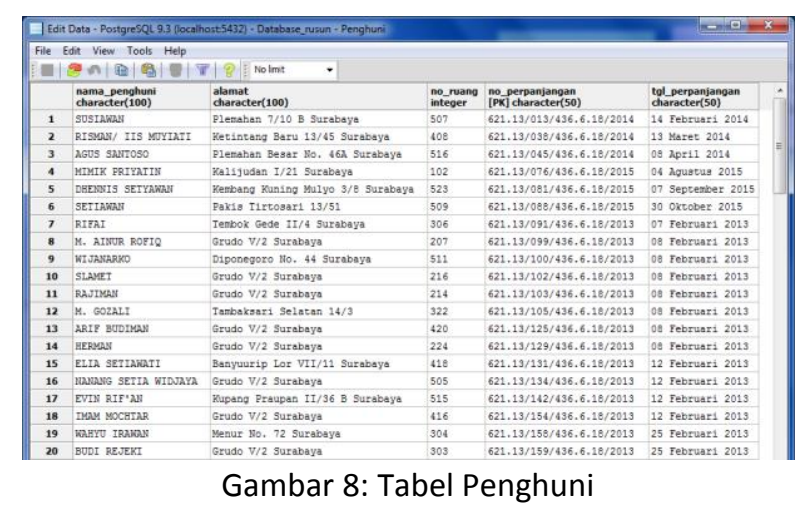

Pembuatan sistem informasi pendaftaran kadaster 3D berbasis web ini dibuat dengan menggunakan perangkat lunak sublime dan menggunakan bahasa pemrograman HTML, CSS dan PHP sehingga menghasilkan tampilan desain website seperti pada Gambar 9 sebagai tampilan awal dari Sistem Informasi.

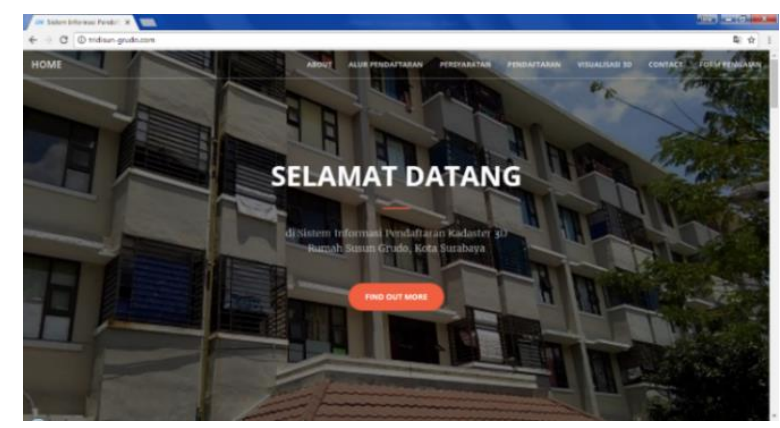

Gambar 9. Tampilan awal
Berikut ini adalah tampilan yang memiliki fungsi untuk mempermudah user/pengguna dalam memahami sistem informasi pendaftaran kadaster 3D berbasis web yang dibuat.

a. Halaman About

Pada tampilan halaman About seperti yang ditunjukkan pada Gambar 10 berisi penjelasan singkat mengenai Rumah Susun Grudo Surabaya. Hal ini berfungsi sebagai informasi awal untuk pengunjung website.

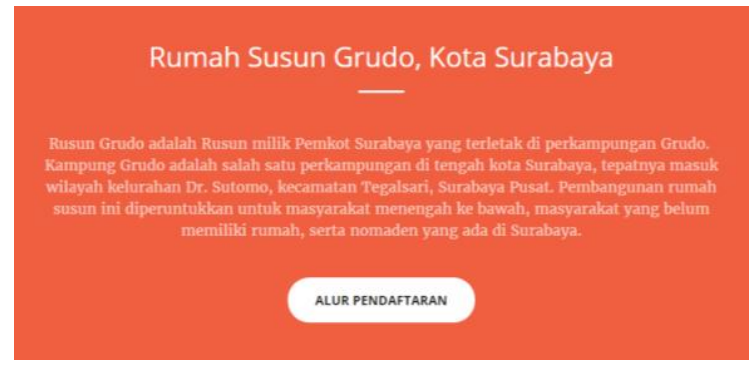

Gambar 10. Halaman About

b. Halaman Alur Pendaftaran

Halaman Alur Pendaftaran seperti yang ditunjukkan pada Gambar 11 menampilkan informasi mengenai mekanisme alur pendaftaran untuk user yang ingin mendaftar sebagai calon penghuni Rumah Susun Grudo Surabaya. Pada halaman ini user dapat mengetahui langkah-langkah yang harus dilakukan mulai dari pendaftaran sampai mendapatkan Surat Izin Pemakaian Rumah Susun.

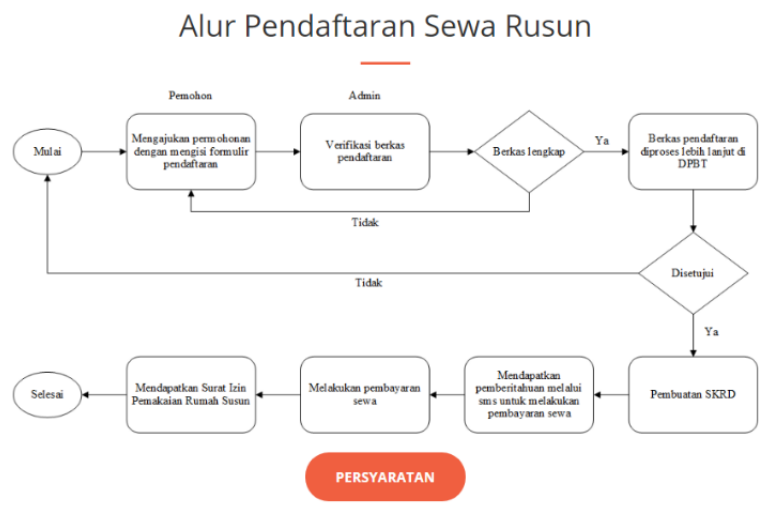

Gambar 11. Halaman Alur Pendaftaran

c. Halaman Persyaratan

Halaman Persyaratan seperti yang ditunjukkan pada Gambar 12 menampilkan informasi mengenai syarat pendaftaran yang ditujukan untuk calon penghuni Rumah Susun Grudo Surabaya dan syarat perpanjangan tinggal yang 
ditunjukan untuk penghuni Rumah Susun Grudo Surabaya pada gambar 13.

\section{d. Halaman Pendaftaran}

Pada halaman Pendaftaran seperti yang ditunjukkan pada Gambar 14 menampilkan formulir pendaftaran yang harus diisi oleh calon penghuni yang ingin mendaftar untuk tinggal di Rumah Susun Grudo Surabaya.

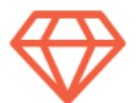

\section{Syarat Pendaftaran}

\begin{tabular}{|l|} 
1. Warga Surabaya \\
2. Mengajukan permohonan secara tertulis kepada \\
Kepala Dinas \\
3. Kartu Tanda Penduduk pemohon yang masih \\
berlaku \\
4. Kartu Keluarga \\
5. Pas foto berukuran $4 \times 6 \mathrm{~cm}$ (empat kali enam \\
sentimeter) terbaru sebanyak 2 (dua) lembar \\
6. Surat Pernyataan yang menerangkan bahwa \\
Pemohon belum mempunyai rumah \\
tinggal/belum memakai satuan rumah susun \\
yang dimiliki, dikelola atau dalam penguasaan \\
Pemerintah Daerah yang diketahui oleh Ketua \\
Rukun Tetangga, Ketua Rukun Warga dan Lurah \\
setempat
\end{tabular}

\section{Gambar 12. Syarat Pendaftaran}

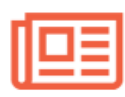

\section{Syarat Perpanjangan}

\section{Tutup}

1. Surat Izin Pemakaian Rumah Susun yang dimohonkan perpanjangan

2. Kartu Tanda Penduduk pemohon yang masih berlaku

3. Kartu Keluarga

4. Pas foto berukuran $4 \times 6 \mathrm{~cm}$ (empat kali enam sentimeter) terbaru

5. Surat Pernyataan yang menerangkan bahwa Pemohon belum mempunyai rumah tinggal yang diketahui oleh Ketua Rukun Tetangga, Ketua Rukun Warga dan Lurah setempat

6. Surat Keterangan gaji/penghasilan yang dikeluarkan oleh Pimpinan pada instansi/perusahaan tempat kerja atau Surat Pernyataan yang menerangkan tentang jumlah

Gambar 13. Syarat Perpanjangan

Formulir Pendaftaran Tinggal di Rumah Susun Grudo

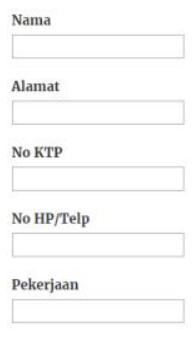

Submit

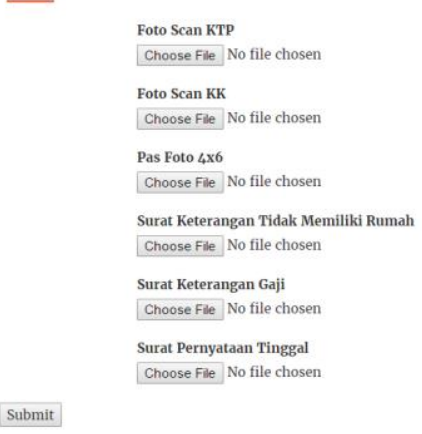

Gambar 14. Halaman Pendaftaran

e. Halaman Visualisasi 3D

Pada halaman Visualisasi 3D seperti yang ditunjukkan pada Gambar 15 menampilkan visualisasi model 3D dari Rumah Susun Grudo dan informasi dari tiap ruang.

\section{f. Halaman Contact Person}

Pada halaman Contact Person seperti yang ditunjukkan pada Gambar 16 menampilkan informasi kontak yang dapat dihubungi oleh user jika user ingin mendapatkan informasi lebih lanjut mengenai website ini.

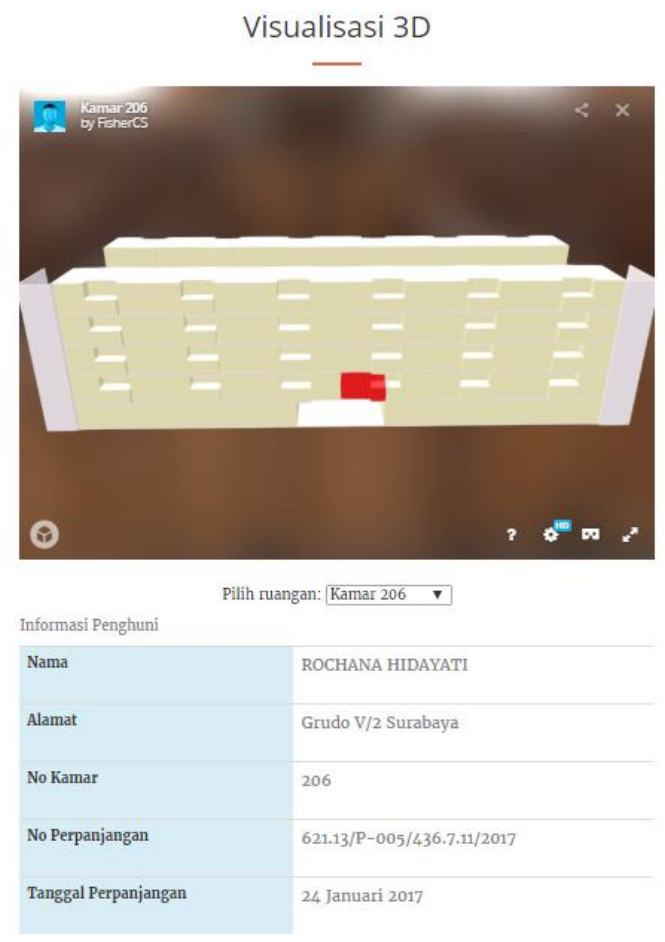

Gambar 15. Halaman Visualisasi 3D 


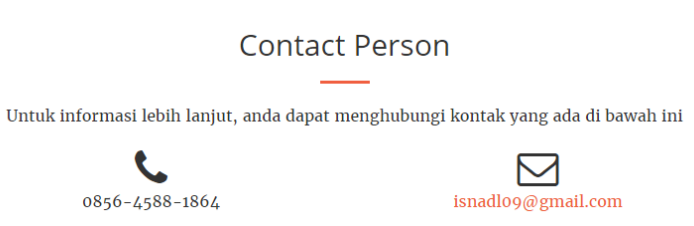

Gambar 16. Halaman Contact Person

g. Halaman Form Penilaian

Pada halaman Form Penilaian seperti yang ditunjukkan pada Gambar 17 menampilkan kuesioner untuk penilaian website. Kuesioner ini berisi 20 pertanyaan mengenai tampilan dari website yang harus dijawab oleh user. Jawaban dari pertanyaan ini terdiri dari 5 kategori jawaban, yaitu Sangat Tidak Setuju, Tidak Setuju, Ragu-ragu, Setuju, dan Sangat Setuju.

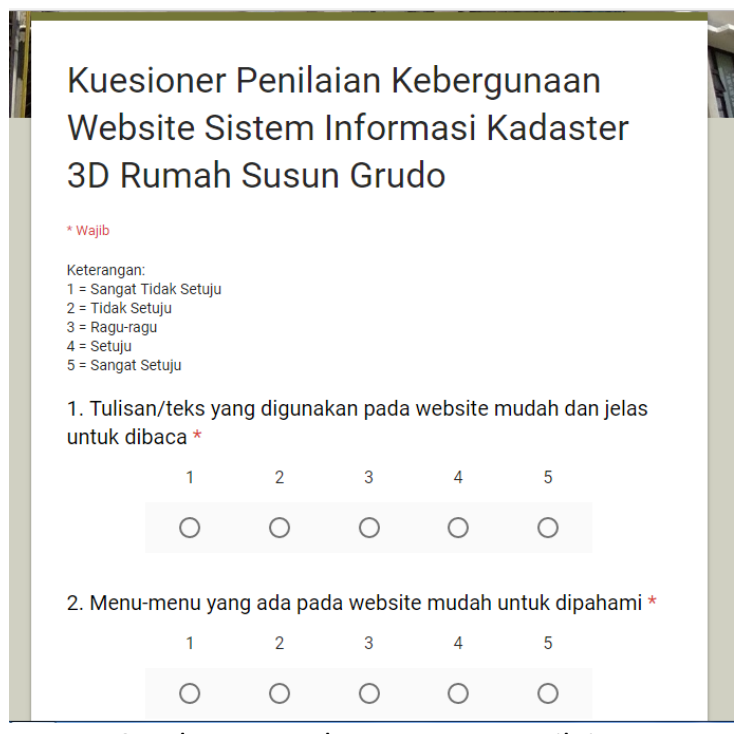

Gambar 17. Halaman Form Penilaian

\section{- Uji Kebergunaan}

Berdasarkan hasil uji kebergunaan ini, terdapat 94 orang responden yang telah mengunjungi website dan melakukan pengisian kuesioner. Dari 94 responden yang mengunjungi website ini 45 orang diantarannya laki-laki dan 49 orang lainnya perempuan. Berdasarkan jenjang pendidikannya, responden dari jenjang perguruan tinggi sebanyak 78 orang dan sisanya dari jenjang SMA. Sedangkan berdasarkan usia responden, responden pada website ini memiliki usia yang bervariasi yakni mulai dari 15 sampai 57 tahun.

Berdasarkan hasil penilaian dari user, selanjutnya dilakukan perhitungan presentase kelayakan website dengan rumus sebagai berikut:

$$
\begin{aligned}
\text { Pskor } & =\frac{\text { skor total }}{i \times r \times 5} \times 100 \% \\
& =\frac{7949}{20 \times 94 \times 5} \times 100 \% \\
& =84,56 \%
\end{aligned}
$$

Dari hasil perhitungan presentase kelayakan website tersebut, maka didapatkan presentase sebesar 84,56\% sehingga website tersebut termasuk dalam kategori sangat layak, sesuai dengan tabel Kategori Penilaian Usability yakni pada rentang nilai $81 \%$ - $100 \%$.

\section{KESIMPULAN}

Berdasarkan hasil penelitian yang telah dilakukan, maka didapatkan beberapa kesimpulan sebagai berikut:

a. Pembuatan model 3D dari Rumah Susun Grudo Surabaya dilakukan dengan menggunakan perangkat SketchUp Make dengan tingkat kedetailan didasarkan pada LOD1.

b. Pembuatan pemodelan sistem basis data kadaster 3D dilakukan dengan membuat perancangan model konseptual, model logikal, model fiskal, dan mengaplikasikannya pada perangkat lunak PostgreSQL.

c. Penelitian ini menghasilkan sebuah website Sistem Informasi Pendaftaran Kadaster 3D dengan domain www.tridisun-grudo.com, yang mana pada website ini model 3D dari Rumah Susun Grudo Surabaya berhasil divisualisasikan.

d. Hasil rekapitulasi kuesioner uji kebergunaan dengan jumlah penilai sebanyak 94 orang responden, didapatkan hasil sebesar 84,56\%, yang termasuk dalam kategori sangat layak.

\section{SARAN}

a. Tingkat ketelitian dari model 3D yang dibuat sebaiknya bisa ditingkatkan yakni lebih dari LOD1 agar model 3D yang dihasilkan lebih riil. Namun apabila digunakan untuk keperluan kadaster, LOD1 sudah cukup untuk menggambarkan obyek bangunan secara 3D.

b. Untuk pembuatan model 3D bangunan yang pada bagian tengahnya terdapat bangunan yang tidak terlihat dari berbagai sisi, baik dari sisi depan belakang maupun dari sisi samping kanan kiri, maka pembuatan model 3D dibuat 
transparan untuk obyek yang tidak terpilih sedangkan obyek yang terpilih berwarna solid.

\section{DAFTAR PUSTAKA}

Budisusanto, Y., Aditya, T., dan Muryanto, R. 2012. "Purwarupa Sistem Informasi Kadaster 3 Dimensi Berbasis Dekstop". The 1st Conference on Geospatial Information Science and Engineering 21-22 November 2012, Yogyakarta

Darmawan, A.L. 2015. Purwarupa Sistem Informasi Kadaster 3D Berbasis Web (Studi Kasus: Rumah Susun Penjaringan Sari, Kota Surabaya). Surabaya: Institut Teknologi Sepuluh Nopember.

Iswanto, F. 2009. Desain dan Visualisasi Basisdata Spasial Kadaster 3D Hibrid (Hybrid Cadastre). Yogyakarta: Jurusan Teknik Geodesi, Fakultas Teknik, Universitas Gadjah Mada.

Julianto, P. A. 2016. Hingga 2025, Kebutuhan Rumah di Indonesia Tembus 30 Juta Unit, <URL:http://bisniskeuangan.kompas.com/read/ 2016/09/17/195151226/hingga.2025.kebutuhan .rumah.di.indonesia.tembus.30.juta.unit.

Dikunjungi pada tanggal 14 Juli 2017, jam 18.30.

Parlindungan, A.P. 2015. Kadaster. Bandung: Institut Teknologi Bandung.

Putra, D.P.E. 2016. Analisa Pembangunan Informasi Spasial 3 Dimensi untuk Pemanfaatan Kadaster 3 Dimensi Multi-Guna (Studi Kasus: Rumah Susun Grudo Surabaya). Surabaya: Institut Teknologi Sepuluh Nopember.

Republik Indonesia. 2011. Undang-Undang No 20 Tahun 2011 tentang Rumah Susun. Lembaran Negara RI Tahun 2011, No. 108. Sekretariat Negara. Jakarta.

Rusmawar, W., Hadwi, S., dan Irawan, S. 2012. Kadaster Masa Lalu dan Masa Mendatang di Indonesia. Bandung: Institut Teknologi Bandung.

Walikota. 2013. Peraturan Walikota Surabaya Nomor 30 Tahun 2013 tentang Pelayanan di Bidang Pemakaian Rumah Susun. Surabaya

Waljiyanto. 2003. Sistem Basis Data: Analisis Dan Pemodelan Data. Yogyakarta: GRAHA ILMU. 